\title{
Pendidikan Anak dalam Islam: Upaya Mempersiapkan Generasi Masa Depan Berakhlak Mulia
}

\author{
Andi Arif Rifa'i \\ Fakultas Tarbiyah \\ IAIN Syaikh Abdurrahman Siddik Bangka Belitung \\ Bangka, Indonesia \\ andiarifrifai@gmail.com
}

\begin{abstract}
Marriage is a sunnatullah for Muslims with one of its aims to develop Islam at the quantitative level. But the development of Islam qualitatively must also get the attention of various groups (parents, society, and government). Highlighting the importance of the role of parents in children's education as one of the closest figures to children, they need to understand how Islam provides concrete examples in educating children. The role of the family in assisting children to reach the stages of their social-intellectual development requires to be following the educational models contained in the Qur'an (such as Lukman's letter) and also the sunnah of the Prophet Muhammad SAW. Golden age (early age) child development needs to get soft touches of education from both parents, without using physical or psychological violence to create generations of great future Muslims.
\end{abstract}

Keywords: Islamic education, child development, early childhood education

\begin{abstract}
Abstrak
Pernikahan merupakan sunnatullah bagi umat muslim dengan salah satu tujuannya untuk mengembangkan Islam dalam tataran kuantitatif. Namun perkembangan Islam secara kualitatif juga harus mendapatkan perhatian dari berbagai kalangan (orang tua, masyarakat dan pemerintah). Menyoroti pentingnya peran orang tua dalam pendidikan anak sebagai salah satu sosok terdekat dengan anak, maka mereka perlu memahami bagaimana Islam memberikan contoh kongkrit dalam mendidik anak. Peran keluaga dalam mendampingi anak mencapai tahap-tahap perkembangan sosial-intelektualnya perlu menauladani modelmodel pendidikan yang tertuang dalam Al-Qur'an (seperti surat Lukman) dan juga sunnah Rasulullah Muhammad SAW. Masa keemasan (usia dini) perkembangan anak perlu mendapatkan sentuhan-sentuhan pendidikan secara lembut dari kedua orang tuanya, tanpa menggunakan kekerasan fisik maupun psiskis guna menciptakan generasi-generasi muslim masa depan yang berakhlak mulia.
\end{abstract}

Kata kunci: pendidika islam, perkembangan anak, pendidikan anak usia dini 


\section{A. Pendahuluan}

Pernikahan ${ }^{1}$ merupakan sunnatullah bagi seluruh umat Islam, yang pada hakekatnya bertujuan untuk membangun keluarga (family building) guna menumbuh kembangkan umat dalam tataran kuantitas. Pertumbahan umat secara kuantitas perlu juga diiringi dengan perkembangan secara kualitatif, baik kualitas lahiriyah maupun kualitas batiniyahnya. Kualitas lahiriyah diwujudkan dalam fisiologis yang kuat, sedangkan kualitas batiniyah didukung dengan kemampuan berfikir dan berperilaku sesuai dengan tuntunan agama. Perkembangan kuantitas umat sebagai produk dari pernikahan hakekatnya merupakan upaya mempertahankan keturunan umat (muslim) melalui anak-anak yang dilahirkan (social interest). Dalam kaca mata Islam anak merupakan sebuah titipan Allah kepada pasangan suami-isteri (orang tua), masyarakat sekaligus bangsa untuk didik dan dikembangkan menuju manusia seutuhnya (insan kamil). Oleh karena itu, maka tugas mempersiapkan anak sebagai generasi masa depan bangsa yang berkualitas (kuat iman, mantap ilmu, baik amal dan mulia akhlak) merupakan tugas bersama (orang tua, masyarakat dan negara/bangsa). ${ }^{2}$

Kesadaran akan peran strategis anak (sebagai generasi penerus bangsa) dalam menopang kemajuan masa depan bangsa, mendorong negara-negara maju tanpa ragu melakukan invesatasi besar-besaran dalam berbagai program pembinaan, pengembangan dan pendidikan terkhusus anak usia dini. ${ }^{3}$ Investasi tersebut didasari oleh kemampuan tumbuh kembang anak yang relatif singkat, sebagian besar berada pada masa usia dini ( 0 sampai 5 tahun). Pada masa usia itulah, anak melewati masa pentig (krusial) perkembangan dalam pembentukan karakter dan kepribadianya, disebut juga dengan masa kritis perkembangan atau masa emas (golden age). Masa ini ditandai dengan berkembangnya kapasitas kecerdasan anak yang mencapai 50 persen dan meningkat menjadi 80 persen pada usia 8 tahun. Oleh karenanya penting dilakukan perangsangan-perangsangan (stimulasi-stimulasi) guna menopang perkembangan optimal organ tubuh, utamanya otak (kognitif) anak. Stimulasi yang dilakukan secara baik akan berdampak pada terbentuknya dasar-dasar sikap dan perilaku serta perkembangan berbagai dimensi kecerdasan seperti; intelektual (intellectual), emosional

\footnotetext{
${ }^{1}$ Menikah menurut Islam dalam buku 'Abdullah Nasih 'Ulwah tahun 2004 yang berjudul Child Education in Islam. Scond Edition,Terjemah M. Mahmoud Ghali dkk penerbit Dar Al-Salam (Kairo). hlm, 18-21, dimaknai dalam tiga hal, yaitu; (1) menikah merupakan sebuah insting manusia (human instinct), (2) menikah merupakan sebuah kepedulian sosial (social interest), dan (3) menikah merupakan sebuah seleksi dan pilihan.

${ }^{2}$ Khairul Hamim. Konsep Pendidikan Anak Dalam Al-Qur'an Surat Luqman. Jurnal Penelitian Keislaman, Vol. 9, No. 1, Januari 2013: 113-127. P.113-114

3 Hadi Siswanto. Permasalahan Pendidikan Dasar Dan Pendidikan Anak Usia Dini. Cendekia, Volume 8, Nomor 2, Oktober 2014. hlm. 144
} 
(emotional), sosial (social), spiritual (spiritual), kinestetik dan seni secara intensif. Masa ini hadir pada diri manusia sekali dalam kehidupan (seumur hidup). ${ }^{4}$ Oleh sebab itu, maka investasi pada wilayah pendidikan anak menjadi sangat penting dan mendesak apabila suatu bangsa berkeiinginan menatap masa depan yang lebih baik.

Investasi pendidikan selain harus mempertimbangkan waktu juga harus mempertimbangkan keterlibatan (kontribusi) berbagai pihak, khususnya peran aktif keluarga dalam mendidik anak-anaknya. Peran keluarga dalam pendidikan anak menurut Islam dapat berwujud bimbingan dan arahan orang tua pada anak-anaknya (keturunannya) agar supaya menjadi anak yang sholeh. Kesalehan anak merupakan investasi masa dapan orang tua yang tidak hanya akan dinikmati di dunia akan tetapi juga di akherat, hal tersebut sejalan dengan hadis nabi Muhammad SAW yang diriwayatkan oleh Muslim dari Abu Hurairah RA yang artinya: "Apabila anak Adam meninggal dunia maka terputuslah segala amal perbuatannya kecuali tiga perkara yaitu sedekah jariah, ilmu yang bermanfaat dan anak yang sholeh yang mendoakan kedua orang tuanya." Hadis ini menegaskan bahwa hubungan orang tua dengan anak-anaknya tidak akan putus meskipun telah meninggal dunia.

Hubungan antara orang tua dan anak pada hakekatnya terbungkus dalam sebuah ikatan keluarga. Dalam kehidupan sosial, keluarga merupakan lingkungan (unit terkecil dari masyarakat) yang panting dalam membentuk kehidupan dan perilaku seorang anak. Artinya keluarga memiliki peran penting dalam membentuk watak dan akhlak anak. Sehingga orang tua sebagai tokoh sentral dalam keluarga, berkewajiban dan bertanggung jawab mendidik anak dengan menanamkan nilainilai (karakter) akhlakul karimah sejak dini. ${ }^{6}$ Pondasi karakter akhlakul karimah yang kuat dan terbangun sejak dini (sejak di lingkungan keluarga) akan menopang perkembangan anak kedepan dalam berbagai aspek; kognitif, afektif dan psikomotor menuju pada kedewasaan atau insal kamil.

Posisi penting keluarga sebagai tempat pertama pembentuk dasar perkembangan anak menjadikannya sering disebut sebagai 'institusi pendidikan'. Institusi dimana anak pertama kali mendapatkan pendidikan dan bimbingan dengan coraknya masing-masing. Pola pendidikan yang didapatkan anak di lingkungan keluarganya akan mempengaruhi perkembangannya selanjutnya. Oleh sebab itu, penting bagi orang tua untuk memberikan pendidikan yang baik, dimana orang tua

\footnotetext{
${ }^{4}$ Hadi Siswanto. hlm. 144-145

5 Khairul Hamim. Konsep Pendidikan Anak Dalam Al-Qur'an Surat Luqman. Jurnal Penelitian Keislaman, Vol. 9, No. 1, Januari 2013: 113-127. P.114

${ }^{6}$ Hayat dan Indriyati. Reaktualisasi Pendidikan Islam Dalam Pengembangan Pola Asuh Anak Sebagai Konsep Revolusi Mental. Epistemé, Vol. 10, No. 1, Juni 2015. 152-153
} 
merupakan guru (pendidik) yang pertama dan utama dalam membentuk kepribadian anak. ${ }^{7}$

Berdasarkan beberapa telaah di atas, maka keluarga dalam Islam memiliki tanggung jawab besar dalam mendidik dan membimbing anak menuju pembentukan akhlakul karimah. Seperti halnya Rasul Muhammad SAW mengemban tugas mulia untuk menyempurnakan akhlak ummat manusia dengan menaruh perhatian besar terhadap pertumbuhan anak sejak kecil (usia dini). Rasul secara tegas memerintahkan para orang tua untuk memberikan bimbingan, pendidikan, pengawasan dan contoh-contoh yang baik agar tumbuh pada diri anak sifat-sifat terpuji dan santun sehingga menjadi kebiasaan (budaya) yang akan tetap dilakukan di fase kehidupan berikutnya. ${ }^{8}$

\section{B. Potensi (Bakat) Anak: Sebuah Anugerah yang Perlu Dikembangkan Sejak Dini}

Orang tua sebagai pengemban amanah terhadap diri anak, perlu memahami dan menyadari bahwa Tuhan memberikan anugerah kepada setiap anak sehingga mereka memiliki potensi-potensi (bakat) bawaan sejak lahir. Anugerah Tuhan yang luar biasa dan tidak ternilai harganya salah satunya adalah anugerah otak ${ }^{9}$. Perlu dipahami bahwa setiap bayi yang dilahirkan dalam otaknya terdapat 100 miliar neuron yang diikat oleh sekitar 1 triliun sel galia. Pada awal perkembangan otak anak akan menghasilkan neuron yang banyak bahkan melebihi kebutuhan. Neuronneuron tersebut akan diperkuat dengan rangsangan, dan yang tidak dperkuat maka akan mengalami atrohy (menyusut dan musnah). Banyaknya sambungan tersebut akan mempengaruhi tingkat kecerdasan anak. Selain itu juga perlu didukung dengan konsumsi makanan yang bergizi, sebagaimana di buktikan oleh hasil riset bahwa gizi anak berpengaruh terhadap kecerdasan atau IQ anak. ${ }^{10}$ Dengan demikian, potensi yang diberikan Tuhan kepada anak (potensi bawaan) dapat berkembang maksimal apabila mendapatkan dukungan dari orang tua berupa stimulus-stimulus yang dibutuhkan anak dalam perkembangannya.

${ }^{7}$ Hasbi Wahy. Keluarga Sebagai Basis Pendidikan Pertama Dan Utama. Jurnal Ilmiah DIDAKTIKA Februari 2012 VOL. XII NO. 2, 245-258. 245-246

${ }^{8}$ Farida. Bimbingan Keluarga Dalam Membantu Anak Autis (Kehebatan Motif Keibuan). Konseling Religi: Jurnal Bimbingan Konseling IslamVol. 6, No. 1, Juni 2015, p,64

${ }^{9}$ Otak merupakan organ maha rumit yang memiliki banyak bagian dan fungsi yang spesifik dan berbeda-beda. Secara garis besar, otak dibagi menjadi tiga bagian utama, yaitu otak besar (cerebrum), otak kecil (cerebellum), dan batang otak (brain stem). Bagian-bagian tersebut masih dibagi menjadi bagian yang lebih kecil. Ruang antar bagian dibatasi oleh cairan otak (cere- brospinal fluid), sementara bagian luarnya terlindungi oleh tiga lapis selaput otak (meninges) dan tulang tengkorak(Supradewi, 2010).

${ }^{10}$ Hadi Siswanto. Permasalahan Pendidikan Dasar Dan Pendidikan Anak Usia Dini. Cendekia, Volume 8, Nomor 2, Oktober 2014. P. 147 
Carla Shatz (dalam Raharjo, 2006) menyadari betapa pentingnya masa emas perkembangan anak dengan menyebutya sebagai windows of opportunity (masa kritis perkembangan) yang memiliki cakupan lima perkembangan penting, yaitu:

1. Perkembangan penglihatan; perangsangan penglihatan perlu dilakukan pada empat tahun pertama masa perkembangan anak.

2. Perkembangan perasaan atau emosi; orang tua harus memperhatikan perubahan (perkembangan) emosi anak selama umur 2 bulan hingga empat bulan. Masa tersebut anak diberikan kasih sayang oleh orang tua, sehingga tumbuh keseimbangan antara perkembangan kognitif dengan perkembangan emosinya. Sehingga berimplikasi pada perkembangan kecerdasan anak sekaligus memiliki kesadaran diri serta mampu menglola enteraksi dengan sesama (interpsersonal).

3. Perkembangan kemampuan bahasa; bahasa anak perlu distimulasi kemampuan bahasanya sejak dalam rahim (kandungan) ibunya. Karena perkembangan awal bahasa anak sangat ditentukan oleh seberapa banyak stimulus-stimulus komunikasi atau dialog (diajak bicara) oleh orang-orang disekitarnya.

4. Perkembangan kemampuan gerak (motorik); masa kritis dari perkembangan gerak (motorik) anak terjadi sejak lahir hingga umur dua tahun. Sehingga pada usia tersebut kemampuan motorik anak harus selalu dirangsang dengan berbagai aktivitas seperti olah raga maupun lainnya, sehingga terbentuk pondasi perkembangan motorik halus maupun kasar anak yang berguna pada tahap selanjutnya.

5. Perkembangan kemampuan musik (musical); perkembangan kemampuan musikal anak berlangsing antara umur tiga sampai sepuluh tahun, namun rangsangan musik hendaknya mulai diberikan sebelum lahir (dalam kandungan). Mozart dalam penelitiannya telah membuktikan bahwa rangsangan musik sejak dini akan membina perkembangan pada bidang visiospatial, matematika serta logika. ${ }^{11}$

Berbagai potensi yang merupakan anugerah dari Tuhan kepada setiap anak, perlu mendapatkan sentuhan-sentuhan pengembangan dalam bentuk pendidikan yang baik sejak dini. Artinya orang tua harus menjadi pendidik yang baik untuk anak-anaknya sehingga potensi yang mereka miliki dapat berkembang dengan maksimal. Masa kritis perkembangan anak telah menempatkan keluarga dalam

11 Hadi Siswanto. Permasalahan Pendidikan Dasar Dan Pendidikan Anak Usia Dini. Cendekia, Volume 8, Nomor 2, Oktober 2014. P. 148-149 
tanggung jawab yang besar. Dimana kondisi tersebut menempatkan keluarga dalam pendidikan dengan terminologi 'pendidikan keluarga'. Konsep demikian itu menjadikan lingkungan keluarga sebagai tempat pertama kali anak berkenalan dengan dunia. Maka pendidikan dalam keluarga akan membawa dampak dan juga menjadi penentu perkembangan anak pada masa-masa selanjutnya.

Pada saat ini, keluarga dihadapkan pada era globalisasi yang membuat tanggung jawab keluarga semakin berat terhadap pendidikan anak-anaknya. Selain mengemban tugas pendidikan orang tua juga diharuskan merawat kesehatan anak, perkembangan fisik, pendidikan, pengembangan intelektual, serta penciptaan nilainilai moral yang lebih baik serta keyakinan dan sikap, kebiasaan berhubungan dengan budaya dan berperilaku baik dalam keluarga maupun masyarakat tempat tinggalnya. ${ }^{12}$ Oleh sebab itu, pada masa awal perkembangan anak, orang tua perlu membekali (mendidik) anak-anaknya dengan:

1. Membimbing baca Al-Qur'an anak

2. Mengajarkan dasar 'Ulumul Syari'ah' (pengetahuan syari' ah) yang mencakup aqidah (kepercayaan/keyakinan), ibadah, dan sirah (sejarah kenabian

3. Mengajarkan adab dan akhlak dalam kehidupan sehari-hari, terhadap orang tua dan keluarga, berurusan dengan masyarakat, mencari pengetahuan, berurusan dengan Al-Qur'an ${ }^{13}$

Pendidikan anak dalam keluarga pada hakekatnya merupakan bagian dari fungsi orang tua (ibu dan ayah). Fungsi orang tua, terutama ibu dalam pendidikan anak, dapat dibagi menjadi dua bagian yaitu: pertama, perlindungan fisik anak, dilakukan dengan memberikan perawatan kesehatan dan serta menyediakan lingkungan yang higienis, sehingga anak dapat hidup sehat di lingkungan rumah. Kedua, perlindungan psikologis, dapat dilakukan melalui pemberian keamanan emosional serta perlindungan psikologis anak, yang dapat dirasakan anak ketika berada disamping ibunya. Selain ibu, ayah juga berperan penting dalam pendidikan anak dengan memberikan support dalam bentuk pnciptaan keluarga harmonis. ${ }^{14}$ Selain itu, orang tua juga harus mengembangkan pola asuh yang baik mendukung perkembangan anak.

\footnotetext{
${ }^{12}$ Ardita Ceka dan Rabije Murati, The Role of Parents in the Education of Children, Journal of Education and Practice, Vol.7, No.5, 2016, 61-64. P-61

13 Raudlotul Firdaus Binti Fatah Yasin dan Raudlotul Firdaus Binti Fatah Yasin. Islamic Education: The Philosophy, Aim, and Main Features, International Journal of Education and Research, Vol. 1 No. 10 October 2013, 1-18.p-13

${ }^{14}$ Ardita Ceka dan Rabije Murati, The Role of Parents in the Education of Children, Journal of Education and Practice, Vol.7, No.5, 2016, 61-64. P-62
} 
Pola asuh yang dikembangkan orang tua dalam keluarga harus mampu menciptakan keseimbangan pertumbuhan kepribadian manusia secara menyeluruh, dengan jalan melatih jiwa, akal pikiran, fisik, ruhaniahnya, karena pada dasarnya pendidikan harus mengupayakan tumbuhnya seluruh potensi manusia. ${ }^{15}$ Orang tua wajib memfasilitasi anak dengan pendidikan terbaik, pendidikan yang komprehensif meliputi semua aspek. ${ }^{16}$ Dalam mengembangkan potensi anak melalui pendidikan dalam keluarga, orang tua harus memperhatikan beberapa elemen memegang peran penting dalam membesarkan dan mendidik anak yaitu;

1. Orang tua harus mengarahkan dan membimbing anak agar belajar dengan tekun.

2. Orang tua harus mengenali minat dan karakter anak.

3. Orang tua harus mengajarkan anak bersosialisasi dengan lingkungan. ${ }^{17}$

Peran penting pendidikan dalam keluarga menempatkan orang tua dalam posisi krusial dalam rantai perkembangan anak. Maka orang tua perlu memahami bagaimana mendidik anak secara baik dan benar sesuai dengan ajaran Islam. Sealin itu, orang tua perlu meneladani bagaimana konsep pendidikan yang telah termaktub dalam Al-Qur'an maupun Sunnah Rasul guna menciptakan generasi masa depan yang berakhlak mulia.

\section{Urgensi Pendidikan Anak dalam Islam}

Pesan-pesan akan pentingnya pendidikan anak dalam Islam terpapar jelas dalam berbagai kisah yang dihadirkan dalam ayat-ayat Al-Qur'an. Kisah-kisah tersebut antara lain; kisah Nabi Ismail kecil (surat Ash-Shaffāt), kisah Nabi Yusuf kecil (surat Yüsuf), dan kisah nasihat Luqman untuk anaknya (surat Luqmān). Keseluruhan dari kisah itu mengandung pesan-pesan pendidikan dan perlindungan anak. Dalam Al-Qur'an juga diketemukan beberapa ungkapan (penyebutan) anak secara etimologi, yaitu: al-awlād (disebut 23 kali dalam 22 surat), al-banūn, alathfāl, alghilmān, al-ghulām, al-wildān. Ghulām juga berkonotasi makna anak yang menakjubkan (kisah nabi Yūsuf dalam surah Yūsuf (12):19) anak laki-laki yang alim (sebutan untuk nabi Ishaq dalam surah al-Hijr (15):53, al-Dzariyāt (51):28), anak laki-laki yang amat sabar (sebutan untuk nabi Ismail, surah alShaffāt (37):101), dan anak laki-laki yatim keturunan orang mukmin (al-Kahfi

${ }^{15}$ Waston, Miftahudin Rois, Pendidikan Anak Dalam Perspektif Psikologi Islam (Studi Pemikiran Prof. Dr. Zakiyah Daradjat), PROFETIKA, Jurnal Studi Islam, Vol. 18, No. 1, Juni 2017 : 27-35. P.27-28

${ }^{16}$ Waston, Miftahudin Rois, Pendidikan Anak Dalam Perspektif Psikologi Islam (Studi Pemikiran Prof. Dr. Zakiyah Daradjat), PROFETIKA, Jurnal Studi Islam, Vol. 18, No. 1, Juni 2017: 27-35. P. ${ }^{3} 4$

${ }^{17}$ Ardita Ceka dan Rabije Murati, The Role of Parents in the Education of Children, Journal of Education and Practice, Vol.7, No.5, 2016, 61-64. P-63 
(18):80-82). ${ }^{18}$ Sejalan dengan hal itu, maka pendidikan dalam Islam memiliki tiga dimensi yaitu:

1. Tarbiyyah, merupakan proses pendidikan yang lebih memberikan penekanan pada perkembangan fisik dan intelektual seorang individu.

2. Ta'dib, merupakan proses pendidikan yang bertujuan untuk pemeliharaan manusia yang baik dengan memberikan pengetahuan agama dan etika mulia sesuai dengan ajaran Islam. Sehingga seorang individu dapat menempatkan dirinya dan berusaha bersama orang lain dalam masyarakat dengan keadilan.

3. Ta'lim, merupakan sebuah proses pendidikan yang didasarkan pada kegiatan pengajaran dan pembelajaran. ${ }^{19}$

Orang tua sebagai sosok yang terdekat dengan anak memiliki peran dalam melakukan tarbiyah, ta'dib dan ta'lim guna mengembangkan IQ, EQ dan SQ awal anak. Dari sisi perkembangan kecerdasan (IQ) anak, pada masa awal menjadi penentu perkembangan selanjutnya. Hal tersebut didukung oleh temuan dari Murray Strauss dalam risetnya, bahwa IQ dari anak-anak yang mengalami kekerasan, maka perkembangannya cenderung statis (mandek) dan kesulitan mengikuti pendidikan pada jenjang yang lebih tinggi. Selain itu, kekerasan yang dilakukan orang tua dalam mendidik anak-anaknya akan berdampak pada perilaku mereka. Sejalan dengan penelitian yang dilakukan Tulane University, bahwa anak usia tiga tahun yang mengalami kekerasan fisik (dari orang tuanya) cenderung menjadi agresif di saat umur lima tahun. Selanjutnya, semakin sering anak mendapatkan kekerasan dari orang tuanya maka semakin lambat perkembangan mentalnya. Mendukung kedua hasil riset tersebut penelitian dari UNICEF tahun 1998 menyebutkan bahwa kejadian traumatik akibat kekerasan baik fisik maupun non fisik (psikis) yang dialami anak akan berakibat buruk bagi perkembangan otak dan kepribadiannya. ${ }^{20}$

Beberapa hasil penelitian di atas sangat menekankan pada pendidikan tanpa kekerasan bagi anak usia dini atau usia di bawah lima tahun. Hal tersebut sejalan dengan ajaran Islam, bahwa orang tua diharuskan mulai memerintahkan atau mengajarkan shalat kepada anak-anaknya sejak umur 7 tahun, dan apabila di umur 10 tahun anak tidak mengerjakan shalat maka dibolehkan orang tua memukul

18 Toni Pransiska. Perlindungan Anak Dalam Perspektif Islam: Antara Idealitas dan Realitas. Jurnal Ilmu Tarbiyah "At-Tajdid”, Vol. 4, No. 2, Juli 2015. P. 49-50

${ }_{19}$ Raudlotul Firdaus Binti Fatah Yasin dan Raudlotul Firdaus Binti Fatah Yasin. Islamic Education: The Philosophy, Aim, and Main Features, International Journal of Education and Research, Vol. 1 No. 10 October 2013, 1-18.p-6

${ }^{20}$ Ali Imron. Re-interpretasi Hadis Tarbawi tentang Kebolehan Memukul Anak Didik. Jurnal Pendidikan Islam Volume I, Nomor 2, Desember 2012/1434. 142 
namun tidak boleh menyakiti (untuk mendidik). Artinya ajaran Islam tidak membolehkan orang tua melakukan kekerasan kepada anaknya pada usia dibawah tujuh tahun. Hal tersebut di dasarkan pada hadist yang diriwayatkan oleh Abu Daud yang artinya:

Perintahkanlah anak-anak kalian untuk shalat saat mereka usia tujuh tahun dan pukullah mereka saat usia sepuluh tahun. Dan pisahkan tempat tidur mereka." (HR Abu Dawud).

Dalam perkembangannya Hadist tentang di bolehkannya memukul anak ini dianalisis oleh para ulama berlaku sama untuk pendidikan secara umum tidak hanya sebatas shalat. Artinya seorang guru dapat memukul muridnya, orang tua boleh memukul anaknya, seorang suami boleh saja memukul istrinya dan lain sebagainya. Tindakan memukul ("kekerasan") tersebut boleh dilakukan atas dasar pendidikan. Selain itu, Para fuqaha juga meyakini bahwa Islam membolehkan kekerasan atas nama pendidikan. Bahkan ada beberpa kelompok yang memahami hadis Abu Dawud tersebut sebagai sebuah bentuk perintah yang wajib dilakukan. Argumen yang digunakan mereka adalah penggunaan kata perintah (fi'il amar), sedangkan dalam kaedah ushul fikih menyatakan bahwa asal pokok dalam kata perintah adalah menunjukkan hukum wajib (al-ashlu fi al-amri li al-wujub). Implikasi maknanya menjadi kekerasan terhadap anak didik terutama yang tidak mau shalat menjadi sesuatu yang wajib dilakukan. ${ }^{21}$

Pemaknaan pembolehan kekerasan dalam mendidik seperti disampaikan oleh Syekh Fauzan dalam Ighatsatul Mustafid bi Syarh Kitab Tauhid dan juga oleh Ibnu Qayim al-Jauziyah, Ali Imron mengkritisinya dengan mengajukan tiga analisa; pertama, ketiadaan indikator yang aplikatif dalam ranah praktiknya (tindakannya). Artinya seorang ayah dapat melakukan pemukulan terhadap anaknya yang menurut asumsi si ayah tidak menyakiti si anak, akan tetapi si anak merasakan hal yang berbeda. Apalagi sebuah tindakan fisik, seperti tindakan pemukulan itu tidak dapat hanya dilihat dari aspek kuantitasnya saja (misalnya, berapa kali pukulan itu dilakukan) namun juga perlu dilihat aspek kualitasnya. Kedua, meskipun sebuah tindakan memukul tersebut secara fisik tidak menyakitkan, akan tetapi jika anak tetap saja sering meninggalkan halat, maka akan muncul pertanyaan berikutnya; lantas cara (tindakan) apa lagi yang harus ditempuh orang tua?. Ketiga, para ulama di atas hanya melihat (mencermati) hadis ini saja dalam aspek pendidikan shalat, namun tidak tampak upaya untuk mencoba menghubungkannya dengan hadis-hadis lain tentang pendidikan secara umum.

${ }^{21}$ Ali Imron. Re-interpretasi Hadis Tarbawi tentang Kebolehan Memukul Anak Didik. Jurnal Pendidikan Islam Volume I, Nomor 2, Desember 2012/1434. P.142 
Mungkin hanya Ibnu Qayyim al-Jauziyyah yang menghubungkannya dengan hadis lain, namun itupun dengan hadis tentang hukuman had yang jelasjelas memiliki spirit yang berbeda. Hukuman had dalam Islam ditujukan untuk pelaku tindak kriminal, sementara anak-anak kita jelas bukan seorang kriminil. Dalam pendidikan shalat, sama sekali tidak di singgung bagaimana Nabi memberikan contoh dengan mengajak cucunya, Hasan dan Husain, untuk shalat berjamaah di masjid bersama para sahabat. ${ }^{22}$

\section{Nabi Mengajarkan Kelembutan Dalam Mendidik Anak}

Hadis tentang pengajaran sholat, seperti diriwayatkan Abu Daud terkait memukul anak, melihat ini orang mungkin akan terburu-buru menyimpulkan bahwa kekerasan memiliki legalitas tersendiri dalam pendidikan Islam. Dengan bermodalkan satu hadis, maka seseorang membuat kesimpulan tersebut. Padahal, ada banyak hadis lain yang justru menunjukkan bahwa Nabi lebih sering menempuh cara-cara penuh kelembutan dan kasih sayang dalam mendidik seseorang. Dalam riwayat Aisyah bahkan dikatakan:

"Sesungguhnya Aisyah R.A. berkata: "Demi Allah, Rasulullah tidak pernah memukul dengan tangannya, baik terhadap isteri maupun terhadap pelayannya, kecuali dia berjihad di jalan Allah."22

Hal yang patut dicatat ialah, redaksi hadis ini memakai kata-kata sumpah. Sampai-sampai Aisyah, isteri beliau bersumpah bahwa nabi tidak pernah memukul seseorang dengan tangannya kecuali saat perang atau jihad di jalan Allah. Ini artinya, nabi tidak pernah mempraktikkan kekerasan dalam mendidik para sahabatnya, baik sahabat yang masih kecil maupun sudah dewasa. Padahal para sahabat yang dewasa itu banyak yang berasal dari suku-suku pedalaman dan beberapa di antara mereka memiliki sifat kasar semacam Umar bin Khatab.

Jika kekerasan dianggap sebagai metode pendidikan yang disunnahkan Nabi, tentulah para sahabat yang dewasa dan kasar itu menjadi orang-orang yang paling banyak meriwayatkan hadis yang berisi tentang pukulan yang mereka terima saat belajar agama Islam dari beliau SAW. Anehnya, kabar tentang kekerasan dalam pendidikan ini justru muncul dalam konteks pendidikan sholat bagi anak kecil. Para sahabat yang sudah dewasa itu lebih kuat sacara fisik maupun psikis dalam menerima tindak kekerasan. Kenapa hadis itu tidak muncul dalam konteks dewasa tersebut?. Informasi yang menarik juga datang dari Anas bin Malik R.A.,

${ }^{22}$ Ali Imron. Re-interpretasi Hadis Tarbawi tentang Kebolehan Memukul Anak Didik. Jurnal Pendidikan Islam Volume I, Nomor 2, Desember 2012/1434. 146-147 
sahabat yang sejak kecil diserahkan oleh ibu kandungnya untuk ikut dan dididik oleh Nabi dengan cara menjadi pembantu beliau. Beberapa sumber sejarah mencatat bahwa Anas dipasrahkan kepada Nabi saat masih usia 10 tahun. Anas bercerita mengenai pengalamannya:

Rasulullah adalah orang yang paling baik akhlaknya. Suatu hari beliau mengutusku untuk suatu keperluan. Demi Allah, aku pun berangkat. Dalam benakku, aku akan berangkat sesuai apa yang diperintahkan Nabi Saw. Aku pun berangkat hingga akhirnya melintasi anak-anak yang sedang bermain di pasar dan bergabung dengan mereka. Tiba-tiba Nabi memegang bajuku dari belakang. Aku melihat beliau tersenyum seraya bersabda, "Wahai Unais,pergilah seperti yang aku perintahkan?" Maka aku pun salah tingkah aku menjawab, "Ya, sekarang aku berangkat wahai Rasulullah.”

Masih tentang Nabi, Anas juga bercerita:

"Demi Allah, aku telah berkhidmat kepada beliau selama sepuluh tahun,beliau tidak pernah berkata untuk sesuatu yang aku lakukan, "Mengapa kamu melakukan ini?" Beliau tidak pernah berkata untuk sesuatu yang aku tinggalkan, "Mengapa kamu tidak mengerjakan ini?" 24

Riwayat di atas membuktikan bahwa Nabi tidak pernah menggunakan kekerasan dalam mendidik Anas bin Malik r.a, sekalipun saat itu Anas masih dalam usia anak-anak. Seandainya Nabi memandang bahwa kekerasan adalah salah satu metode yang baik dan layak diapakai untuk mendidik, niscaya beliau telah mempraktikkannya kepada Anas jauh-jauh hari sejak dulu kala. Buktinya, Nabi Saw. lebih memilih cara lain yang terbukti lebih efektif membekas dalam benak para sahabatnya semacam Anas bin Malik tadi. ${ }^{23}$

Ibn Khaldun berpendapat bahwa anak yang dididik berdasarkan paksaan dan kekerasan cenderung tumbuh menjadi orang yang suka berbuat kasar, tidak mampu mengontrol emosi, kehilangan kreativitas, suka berbohong dan membuat muslihat agar terhindar dari hukuman orang tua. Anak seperti itu akan terdorong untuk melakukan kebohongan, muslihat dan kejahatan. ${ }^{24}$

${ }^{23}$ Ali Imron. Re-interpretasi Hadis Tarbawi tentang Kebolehan Memukul Anak Didik. Jurnal Pendidikan Islam Volume I, Nomor 2, Desember 2012/1434. P.151-152

${ }^{24}$ Hayat dan Indriyati. Reaktualisasi Pendidikan Islam Dalam Pengembangan Pola Asuh Anak Sebagai Konsep Revolusi Mental. Epistemé, Vol. 10, No. 1, Juni 2015 . p.165 
Dalam sebuah buku yang berjudul "Tarbiyatul aulad fil Islam" yang di tulis oleh Dr. Abdullah Nasih Ulwan, beliau menyebutkan lima metode yang perlu dilakukan orang tua dalam mendidik anak-anaknya agar sang anak kelak menjadi anak yang shaleh dan shalehah. Metode tersebut adalah Pertama, mendidik anak dengan keteladanan yang baik. Orang tua harus memberikan contoh-contoh yang baik setiap harinya kepada anaknya dalam semua tindakannya. Ini berarti kalau orang tua ingin memiliki anak yang shaleh maka yang shaleh terlebih dahulu adalah dirinya sendiri, karena bagaimana mungkin ia akan membentuk pribadi seorang anak menjadi shaleh jika ia sendiri tidak berprilaku shaleh. Kedua, mendidik anak dengan pembiasaan-pembiasaan yang baik. Berarti segala hal yang baik di dalam Islam sudah harus diaksanakan oleh sang anak meskipun dia masih kecil, dan itu pula sebabnya mengapa sang anak sudah harus melaksanakan shalat pada saat sang anak berumur tujuh tahun, padahal anak yang berumur tujuh tahun itu masih belum wajib hukumnya mengerjakan shalat. Ini tentu maksudnya agar anak terbiasa melaksanakan ajaran Islam. Pembiasaan-pembiasaan yang baik harus ditanamkan kepada anak sejak kecil.

Ketiga, mendidik dengan pengajaran dan dialog. Hal ini berarti setelah anak mendapat keteladanan dari orang tuanya lalu dibiasakan juga untuk melakukan sesuatu, maka ketika diberi pengajaran tentang sesuatu yang harus dilaksanakannya itu, sang anak akan mudah memahami dan menerima pengajaran. Apalagi pengajaran tersebut diajarkan dengan cara dialog antara orang tua dengan anaknya, sebagaimana yang dilakukan oleh Nabi Ibrahim pada saat ia diperintahkan untuk menyembelih Ismail As.

Keempat, mendidik dengan cara memberi hukuman atau sanksi bila anak tidak mau melaksanakan sesuatu yang diperintahkan agama, sementara ajakan dengan cara lemah lembut sudah dilakukan namun tidak membuat sang anak mau berubah ke arah yang lebih baik. Isyarat memberi sanksi atau hukuman kepada sang anak ini dapat dipahami dari hadith yang Artinya: "Suruhlah anak-anakmu shalat bila berumur tujuh tahun dan pukullah jika mereka sudah berumur sepuluh tahun"(H.R. Abu Daud).

Dari hadith di atas dapat dipahami bahwa mendidik anak harus ada disiplin dan ketegasan di dalamnya sehingga anak menjadi tahu dan sadar mana yang harus dikerjakan dan mana yang harus ditinggalkannya. Sementara itu, kata pukul dalam hadith tersebut di atas bisa saja dimaknai dengan sanksi dan orang tualah yang paling tahu sanksi yang paling tepat untuk diberlakukan kepada anak-anaknya.

Kelima, metode dengan pengawasan dan nasehat. Berarti orang tua harus mengawasi atau mengontrol aktivitas anaknya. Jika ia menjumpai anaknya melakukan hal yang kurang baik maka tugas orang tua untuk memberi nasehatnasehat dengan cara yang baik dan penuh kasih sayang sebagaimana yang 
dilakukan Lukman yang diceritakan dalam al-Qur'an surat Luqman: 12-19. Beberapa tips mendidik anak di atas sangat baik untuk dicoba dan dipraktikkan dalam kehidupan sehari-hari, terlebih lagi jika disempurnakan dengan memperhatikan lebih detail nasehat Lukman kepada anaknya sebagaimana yang telah dipaparkan oleh Allah dalam Alqur'an surah Luqman ayat 12-19. Nasehatnasehat Luqman yang tercantum di dalam al-Qur' an inilah yang perlu diikuti dalam mendidik anak dalam Islam. Profile kesalehan keluarga Luqman ini sangat penting untuk dijadikan panutan dalam mendidik anak guna mewujudkan generasi yang unggul baik unggul secara intelektual maupun spiritual. ${ }^{25}$

\section{E. Luqman Sebagai Tauladan Pendidikan Anak dalam Islam}

Zakiah Daradjat berpendapat bahwa pendidikan moral yang paling baik terdapat dalam agama, karena nilai moral yang dapat dipatuhi dengan suka rela, tanpa paksaan dari luar hanya dari kesadaran sendiri, datangnya dari keyakinan beragama. ${ }^{26}$ Dalam ajaran agama Islam masalah akhlak mendapat perhatian yang sangat besar sebagaimana sabda nabi, "Sempurnanya iman seorang mukmin adalah mempunyai akhlak yang bagus". Dan dalam riwayat lain dikatakan "Sesungguhnya yang dicintai olehku (Nabi Muhammad SAW) adalah mereka yang mempunyai akhlak yang bagus". Mengingat masalah akhlak adalah masalah yang penting seperti sabda nabi di atas maka dalam mendidik dan membina akhlak sang anak, orang tua dituntut untuk dapat berperan aktif. Peran utama orang tua sebagai pendidik dalam menanamkan nilai-nilai akhlak karimah kepada anaknya sebaiknya berdasarkan ajaran agama Islam agar anak dapat melaksanakan fungsi sosialnya sesuai dengan norma agama, norma hukum, norma kesusilaan dan dengan akhlak yang mulia. ${ }^{27}$

Menarik untuk disimak bahwa Al-quran mengabadikan perbincangan yang terjadi antara Luqman dengan anaknya sebagaimana yang tertera dalam surat Luqman ayat 13 yang Artinya: "Dan (Ingatlah) ketika Luqman Berkata kepada anaknya, di waktu ia memberi pelajaran kepadanya: "Hai anakku, janganlah kamu mempersekutukan Allah, Sesungguhnya mempersekutukan (Allah) adalah benar-benar kezaliman yang besar".

Sebelum turunnya ayat di atas, terlebih dahulu turun ayat yang menjelaskan tentang sebagian dari hikmah yang dianugerahkan kepada Luqman

${ }^{25}$ Khairul Hamim. Konsep Pendidikan Anak Dalam Al-Qur'an Surat Luqman. Jurnal Penelitian Keislaman, Vol. 9, No. 1, Januari 2013: 113-127. P.115-117

${ }^{26}$ Hasbi Wahy. Keluarga Sebagai Basis Pendidikan Pertama Dan Utama. Jurnal Ilmiah DIDAKTIKA Februari 2012 VOL. XII NO. 2, 245-258. P.255

${ }^{27}$ Hayat dan Indriyati. Reaktualisasi Pendidikan Islam Dalam Pengembangan Pola Asuh Anak Sebagai Konsep Revolusi Mental. Epistemé, Vol. 10, No. 1, Juni 2015 . p.153 
adalah perintah untuk bersukur anas nikmat yang diberikan. Tentu saja salah satu nikmat tersebut adalah anak. Dan mensukuri kehadiran anak adalah dengan mendidiknya.

Bila kita memperhatikan ayat 13 surah Luqman di atas, Allah Swt.. menjelaskan secara jelas mengenai ucapan-ucapan Luqman ketika mendidik anaknya. Pada ayat tersebut Luqman memanggil anaknya dengan panggilan mesra, "Ya Bunayya," hai anakku, sebagai isyarat bahwa mendidik anak haruslah didasari oleh rasa kasih sayang terhadap peserta didiknya.

Pada ayat di atas, Luqman memulai nasehatnya dengan menekankan perlunya menghindari shirik (mempersekutukan Allah). Larangan ini sekaligus mengandung pengajaran tentang wujud dan keesaan Tuhan. Bahwa redaksi pesannya berbentuk larangan, adalah karena setiap keburukan apalagi syirik haruslah terlebih dulu dihilangkan sebagaimana ungkapan yang menyatakan "altakhliyyat muqaddamun 'ala at-tahliyyah" (penyingkiran keburukan harus didahulukan dari penyandangan hiasan).

Setelah Luqman menasehati anaknya untuk mendirikan shalat, lalu ia menasehati anaknya untuk berdakwah di jalan Allah dengan cara menyeru kepada kebaikan dan melarang dari kejahatan (amar ma'ruf nahi munkar), sebagaimana dikemukakan pada ayat selanjutnya: "Hai anakku, laksanakan shalat (secara bersinambung dan sempurna) dan suruhlah (orang lain) mengerjakan yang makruf dan mencegah (mereka) dari mengerjakan yang mungkar dan bersabarlah terhadap apa yang menimpa kamu sesungguhnya yang demikian itu termasuk halhal yang diwajibkan (oleh Allah) "(Qs. Luqman [31]: 17).

Dalam nasehat itu secara implisit disebutkan bahwa amar ma'ruf nahi munkar adalah setelah mendirikan shalat. Karena dengan shalat ia dapat berhubungan dengan Tuhannya dan mendapatkan kekuatan dan ketegaran, juga keberanian. Dengan shalat, orang akan bertambah keimanannya yang dapat membantunya melaksanakan dakwahnya. Dengan shalat juga ia menjadi orang yang tidak suka kepada kejahatan maka ia melarang orang dari kejahatan itu.

Komitmen untuk melakukan amar ma'ruf nahi munkar itu disadari oleh Luqman seringkali tidak berjalan mulus. Namun pasti ada hambatan, rintangan bahkan juga tantangan dan cobaan. Oleh karena itu ia melanjutkan nasehatnya kepada anaknya agar tetap bersabar terhadap segala macam musibah yang menimpa. Orang yang menyeru kepada Allah, menasehati manusia dan menganjurkan mereka untuk berbuat kebaikan atau melarangnya berbuat jahat, berarti ia harus siap secara mental untuk menerima segala resiko yang ada seperti dihina, dicaci maki, bahkan tidak jarang mendapat ancaman fisik. Jika ia tidak mempunyai bekal kesabaran yang cukup, niscaya ia tidak akan bisa istiqamah di dalam menjalankan perannya dalam berdakwah. Menyuruh mengerjakan yang 
makruf, mengandung pesan untuk mengerjakannya terlebih dahulu karena tidaklah wajar menyuruh orang lain sebelum diri sendiri mengerjakannya.

Sedangkan yang dimaksud dengan makruf adalah segala sesuatu yang diakui oleh adat istiadat masyarakat sebagai hal yang baik selama tidak bertentangan dengan nilai-nilai akidah dan syari'at. Akhirnya nasehat Luqman kepada anaknya ditutup dengan kewajiban bersikap lemah lembut terhadap orang lain, sopan dalam berjalan dan berbicara. Sebagaimana Firman Allah yang Artinya:

"Dan janganlah kamu memalingkan mukamu dari manusia (karena sombong) dan janganlah kamu berjalan di muka bumi dengan angkuh. Sesungguhnya Allah tidak menyukai orang-orang yang sombong lagi membanggakan diri. Dan sederhanalah kamu dalam berjalan dan lunakkanlah suaramu. Sesungguhnya seburuk-buruk suara ialah suara keledai." (Qs. Luqman [31]: 19)

\section{F. Kesimpulan}

Keluarga merupakan wujud implementasi Sunnatullah. Tujuan dibentuknya keluarga dalam Islam adalah untuk mengembangkan ummat Islam baik secara kuantitas maupun kualitas. Untuk dapat memenuhi tujuan tersebut potensi anak harus dikembangkan melalui pendidikan yang baik dan berlandaskan nilai-nilai ajaran Agama. Pendidikan harus dimulai sejak dini (masa golden age) untuk mendapatkan hasil yang maksimal.

Pendidikan dalam Islam didasarkan pada ajaran Al-Qur'an dan Hadis. Keluarga sebagai penopang awal pendidikan harus berperan secara maksimal, sebagaimana dicontohkan dalam Al-Qur'an Surat Luqman, dimana Luqman memberikan tauladan bagaimana mendidik anak dalam keluarga dengan baik. Dengan pendidikan yang baik dalam keluarga anak dapat berkembangkan IQ (Intelligent Quotion), EQ (Emotional Quotion) dan SQ (Spiritual Quotion)nya secara seimbang, membentuk manusia-manusia masa depan berahlak mulia.

${ }^{28}$ Khairul Hamim. Konsep Pendidikan Anak Dalam Al-Qur'an Surat Luqman. Jurnal Penelitian Keislaman, Vol. 9, No. 1, Januari 2013: 113-127. P.120-123 


\section{DAFTAR PUSTAKA}

'Abdullah Nasih 'Ulwah. 2004. Child Education in Islam. Second Edition. Terjemah M. Mahmoud Ghali dkk. Kairo: Dar Al-Salam.

Hamim, Khairul. Konsep Pendidikan Anak Dalam Al-Qur'an Surat Luqman. Jurnal Penelitian Keislaman, Vol. 9, No. 1, Januari 2013: 113-127.

Siswanto, Hadi. Permasalahan Pendidikan Dasar Dan Pendidikan Anak Usia Dini. Cendekia, Volume 8, Nomor 2, Oktober 2014

Hayat dan Indriyati. Reaktualisasi Pendidikan Islam Dalam Pengembangan Pola Asuh Anak Sebagai Konsep Revolusi Mental. Epistemé, Vol. 10, No. 1, Juni 2015.

Farida. Bimbingan Keluarga Dalam Membantu Anak Autis (Kehebatan Motif Keibuan). Konseling Religi: Jurnal Bimbingan Konseling IslamVol. 6, No. 1, Juni 2015

Pransisk, Toni. Perlindungan Anak Dalam Perspektif Islam: Antara Idealitas dan Realitas. Jurnal Ilmu Tarbiyah “At-Tajdid”, Vol. 4, No. 2, Juli 2015.

Imron, Ali. Re-interpretasi Hadis Tarbawi tentang Kebolehan Memukul Anak Didik. Jurnal Pendidikan Islam Volume I, Nomor 2, Desember 2012/1434.

Wahy, Hasbi. Keluarga Sebagai Basis Pendidikan Pertama Dan Utama. Jurnal Ilmiah Didaktika Februari 2012 VOL. XII NO. 2, 245-258. 